\title{
Analisis Kelayakan Investasi Dendeng Daging Sapi (Studi Kasus di PD “Carole Jaya”)
}

\author{
Lia Milana $^{1 *}$ dan Whydiantoro ${ }^{2}$ \\ ${ }^{1}$ Program Studi Tehnik Industri, Universitas Majalengka, Indonesia \\ ${ }^{2}$ Program Studi Tehnik Industri, Universitas Majalengka, Indonesia
}

\begin{abstract}
:
Beef trading industry in Indonesia is growing, both in terms of quantity and quality lead to the emergence of intense competition, therefore every trading company is required to be creative in the face of business competition in order to meet and satisfy the needs and desires of consumers. One way is through product development. One way is through product development. Product development is an important thing for a company to maintain its existence or at least can guarantee the survival of the company. It is also encouraging PD Carole Jaya which is engaged in beef and mutton trade, to create a new innovation that is the development of beef products by making beefjerky, as an alternative in the development of beef products and to increase sales productivity for maintaining the existence of its business. But of course, in the development of this product, should consider the investment plan, whether worthy or not product development is done, given the amount of capital required for the manufacture of this jerky. In the development of this product, there are three stages of the activities undertaken: preparation, execution (manufacturing process) and final stage. In the final stage of the activities undertaken is to process data, analyze the results of research and make conclusions. In this financial data processing using financial feasibility analysis tool with PayBack Period method, ARR (Average Rate of Return), NPV (Net Present Value), IRR (Internal Rate of Return) and (R / C Ratio) Business Efficiency and BEP (Break Event Point). The results of the investment analysis show that the PBP (Payback Period) of this investment is 3 months, ARR (Average Rate of Return) of 1.35\%, NPV (Net Present Value) generated 27.998.634, - which means when NPV> 1, then the feasible investment, PI (Profitability Index) of 1.35 means that the investment can be run (Feasible), $R / C$ Ratio of 1.35 means is, this investment is very efficient and profitable and BEP (production) of Rp. 258,500, - and BEP (unit) of $44.4 \mathrm{~kg}$. Thus, the product development effort by making beef jerky is feasible to be implemented by PD. Carole Jaya.
\end{abstract}

Keywords: company existence, business feasibility, product development innovation, Increased sales productivity, business feasibility analysis tool

\section{PENDAHULUAN}

Latar Belakang

Daging sapi merupakan salah satu pilihan bahan makanan yang banyak

*Email korespondensi:

milanalia888@yahoo.co.id digemari di Indonesia. Selain lezat, daging sapi sendiri juga kaya akan manfaat yang sangat penting bagi tubuh manusia. Daging sapi memang bermacam jenisnya, akan tetapi kandungan gizi dan manfaat daging sapi dari segala macam dan jenis kurang lebih adalah sama. 
Semua daging sapi menawarkan manfaat yang sama. Hanya saja mungkin bagi sebagian orang mengkonsumsi daging sapi yang mahal seperti daging Has Dalam terasa lebih enak dagingnya. Daging sapi sendiri sering diolah menjadi berbagai macam olahan lezat yang menggoyang lidah. Kita juga perlu mengetahui manfaat daging sapi yang penting bagi tubuh kita, diantaranya adalah :

\section{Protein}

Salah satu kandungan gizi dalam daging sapi yang sangat bermanfaat bagi tubuh manusia adalah protein. Protein memang dapat kita dapatkan dengan mengkonsumsi telur, bahkan juga tahu dan tempe. Akan tetapi, sumber protein hewani yang sangat besar adalah berasal dari daging sapi. Lalu kenapa protein ini sangat penting bagi tubuh? Karena protein membantu tubuh manusia untuk membentuk otot sehingga menambah masa otot dan pada akhirnya dapat menambah berat badan kita. Selain itu, protein ini juga sangat penting dalam masa pertumbuhan anak-anak.

\section{Zat besi}

Dalam daging sapi terdapat kandungan zat besi yang sangat tinggi. Kandungan zat besi ini sangat bermanfaat bagi tubuh manusia karena dapat menghindarkan kita dari anemia. Selain itu, jika seseorang terkena anemia, daging sapi juga dapat menjadi salah satu alternative obatnya. Anemia dapat menyebabkan seseorang merasa lemas dan lesu sehingga mengganggu produktivitas dan aktivitasnya sehari-hari, oleh karenanya, anemia ini perlu sangat dihindari. Zat besi bagi tubuh manusia juga dapat menjadi benteng pertahanan melawan penyakit karena dapat meningkatkan dan memperbaiki sistem kekebalan tubuh. Dengan tubuh yang kebal melawan penyakit dan terhindar dari anemia sehingga dapat tetap aktif, zat besi memberikan nutrisi bagi anak untuk dapat tumbuh dan mempunyai semangat belajar yang tinggi.

\section{Selenium dan Zinc}

Selenium merupakan suatu zat yang membantu tubuh manusia untuk meningkatkan sistem kekebalan tubuhnya, hampir mirip dengan fungsi dari zat besi yang juga dapat meningkatkan sistem imun manusia. Zat lain yang juga membantu tubuh manusia meningkatkan kekebalannya adalah zinc. Dengan zinc, tubuh manusia selain mempertahankan sistem kekebalan tubuh, juga membantu pria untuk memproduksi sperma dengan baik dan mencegah kerusakan pada organ reproduksinya.

\section{Vitamin B kompleks}

Bagi Anda yang diharuskan bekerja dengan mengandalkan konsentrasi dan daya ingat, kita pasti akan membutuhkan daging sapi karena mengandung vitamin B kompleks yang berfungsi mempertajam daya ingat kita dan membuat kita dapat berkonsentrasi dengan lebih baik. Vitamin B kompleks ini tentu saja akan sangat berguna bagi anak kita yang masih duduk di bangku sekolah demi meningkatkan prestasinya.

\section{Omega 3}

Selain terkandung pada ikan, omega 3 juga terkandung dan banyak terdapat pada daging sapi. Manfaat daging sapi yang kita dapatkan akan membantu kita untuk membantu menjaga dan memelihara sistem saraf pusat yaitu biasa kita sebut dengan otak, membantu fungsi jantung dan hati.

\section{Lemak}

Daging sapi tidak terlepas dari lemak yang dikandungnya, fungsi lemak sendiri adalah untuk meningkatkan energi dan sumber tenaga bagi tubuh untuk menjalani aktivitas sehari-hari. Selain manfaat berdasarkan kandungan gizinya, kita dapat melihat dari aspek kesehatan langsung, berikut adalah daftar manfaatnya berdasarkan fungsi bagi kesehatan tubuh.

1. Membangun otot agar tumbuh lebih kencang dan kuat

2. Sumber energi yang besar

3. Menjaga hidup sehat untuk segala umur

4. Mencegah diabetes dan obesitas 
5. Mengatur berat badan

6. Kesehatan kognitif (otak)

7. Menyembuhkan luka

8. Menjaga sistem kekebalan tubuh

9. Mencegah anemia

10. Meningkatkan sel darah merah

11. Meningkatkan kesehatan kulit

12. Mencegah stroke dan serangan jantung.

Namun di sisi lain, daging sapi segar memiliki masa kadaluarsa yang pendek apabila penempatan dan pengemasannya tidak tepat, karena daging merupakan bahan makanan segar bukan olahan dan tanpa pengawet, hal ini dikhawatirkan akan menjadi penyebab menurunnya kredibilitas PD. Carole Jaya di mata masyarakat (konsumen) yang selalu menginginkan daging sapi segar dan sehat, sementara kuantitas penjualan daging sapi segar di PD. Carole Jaya selalu mengalami perubahan (tidak tetap) karena tingkat permintaan pasar yang selalu berubah, kadang tinggi kadang rendah. Hal ini yang menjadi alasan pertimbangan perusahaan dagang PD. Carole Jaya yang bergerak di bidang penjualan daging sapi segar untuk melakukan pengembangan dengan membuat produk baru yang berbahan daging sapi segar sebagai solusi alternatif menghadapi permasalahan yang dihadapi. Untuk itu, PD. Carole Jaya mengembangkan produk olahan daging sapi berupa Dendeng Sapi sebagai salah satu cara pengawetan daging dan juga untuk meningkatkan nilai jual dari daging sapi tersebut, namun pengembangan produk ini perlu dilakukan kajian dan analisis investasi untuk memperhitungkan kelayakan investasi dari usaha pembuatan dendeng sapi.

\section{Rumusan Masalah}

Berdasarkan latar belakang yang telah dikemukakan di atas, maka peneliti merumuskan beberapa masalah sebagai berikut :

a. Bagaimana upaya yang dilakukan PD. Carole Jaya untuk mempertahankan eksistensi usahanya? b. Bagaimana kelayakan Investasi dalam usaha Dendeng Daging Sapi di PD. Carole Jaya dilihat dari aspek keuangan (Cash Flow)

\section{Tujuan Penelitian}

Berdasarkan rumusan masalah tersebut di atas, maka dapat diurai tujuan dari penelitian ini adalah untuk mengetahui :

a. Upaya yang dilakukan oleh PD. Carole Jaya guna mempertahankan eksistensi usahanya

b. Proses pembuatan dendeng daging sapi yang dilakukan oleh PD. Carole Jaya

c. Kelayakan investasi dalam usaha pembuatan dendeng daging sapi pada PD Carole Jaya.

\section{KAJIAN LITERATUR}

Feasibility study adalah kegiatan untuk menilai sejauh mana manfaat yang dapat diperoleh dalam melaksanakan suatu kegiatan usaha. Hasil analisis ini digunakan sebagai bahan pertimbangan dalam mengambil keputusan, apakah menerima atau menolak dari suatu gagasan usaha. Pengertian layak dalam penelitan ini adalah kemungkinan dari gagasan suatu usaha yang akan dilaksanakan dapat memberikan manfaat dalam arti finansial maupun sosial benefit. Dengan adanya analisis kelayakan ini diharapkan resiko kegagalan dalam memasarkan produk dapat dihindari (Lubis, 2014).

\section{Pengertian Investasi}

Secara umum, investasi merupakan kegiatan menanamkan modal jangka panjang, dimana selain investasi tersebut perlu pula disadari dari awal bahwa investasi akan diikuti oleh sejumlah pengeluaran lain yang secara periodik perlu disiapkan. Disamping pengeluaran, investasi akan menghasilkan sejumlah keuntungan atau manfaat (Giatman, 2011). 


\section{Pengertian Aliran Kas (Cash Flow)}

Cash Flow adalah tata aliran uang masuk dan keluar per periode waktu pada suatu perusahaan yang terdiri dari Cash In (Uang masuk) yang berasal dari penjualan produk atau manfaat terukur/benefit dan Cash Out (Uang keluar) merupakan kumulatif dari biaya-biaya (cost) yang dikeluarkan. (Giatman, 2011).

\section{METODE}

\section{Metode Penelitian}

Penelitian ini akan dilakukan di PD Carole Jaya yang beralamat di Pasar Cigasong Kecamatan Cigasong Kabupaten Majalengka pada bulan Maret 2018 sampai dengan Desember 2018. Penelitian ini dilakukan dengan cara survei langsung ke lapangan dengan mengamati proses penjualan dan mengkaji aliran kas dari penjualan dendeng daging sapi selama 6 bulan (PD. Carole Jaya).

\section{Jenis dan Teknik Pengumpulan Data}

Adapun jenis data dalam penelitian ini ialah data kuantitatif berupa data biaya investasi untuk asset tetap seperti tanah, gedung, dan peralatan lainnya; data biaya tetap dan biaya variabel yang berkaitan; aliran kas penjualan dendeng, serta biaya lainnya dan data kualitatif berupa keterangan, informasi, penjelasan, pendapat dan tanggapan dari pemilik.

\section{Metode Analisis Data}

1. Analisis aspek dalam studi kelayakan Investasi

Aspek yang dilihat untuk analisis kelayakan investasi ini hanyalah aspek keuangannya saja, yaitu membahas mengenai penyusunan modal kerja dan modal investasi.

2. Alat Analisis Kelayakan Investasi

a. Metode Pay Back Periode

Payback Periode (PBP) merupakan perhitungan atau penentuan jangka waktu yang dibutuhkan untuk menutupi modal awal dari suatu proyek dengan menggunakan arus kas masuk yang dihasilkan oleh proyek tersebut. Rumus yang digunakan adalah:

Payback Periode $=\left[t+\frac{b-c}{d-c}\right] \times 12$ Bulan

Payback Periode $=$

$$
\left[\frac{\text { Jumlah Investasi X } 12 \text { Bulan }}{\text { Aliran Kas Bersih }}\right]
$$

Keterangan:

$\mathrm{T}=$ Tahun terakhir dimana kumulatif net cash belum mncapai initial Investment

$\mathrm{b}=$ Initial Investment (Modal Awal)

$\mathrm{c}=$ Kumulatif Net Cash Inflow pada tahun $\mathrm{ke}-\mathrm{t}$

$\mathrm{d}=$ Kumulatif Net Cash Inflow pada tahun $\mathrm{ke}-\mathrm{t}+1$

Periode:

Kriteria penilaian dalam Payback

- Jika Payback Periode < Waktu Maksimum, maka usulan proyek dapat diterima

- Jika Payback Periode > Waktu Maksimum, maka usulan proyek tidak dapat diterima / Ditolak

b. Metode ARR (Average Rate Of Return)

Merupakan cara untuk mengukur rata-rata pengembalian bunga dengan cara membandingkan antara rata-rata laba sebelum pajak EAT dengan rata-rata investasi.

$$
\begin{aligned}
& \text { Kata - rata EAT } \\
& \text { ARR }: \frac{\begin{array}{c}
\text { (Average Earning After Tax) } \\
\text { Rata - rata Investasi } \\
\text { (Average Investment) }
\end{array}}{\text { Rata }- \text { rata EAT }: \frac{\text { Total EAT }}{\text { Umur Ekonomis (n) }}} \\
& \text { Rata2 Investasi }: \frac{\text { Investasi }}{\text { Umur Ekonomis (n) }} \\
& \text { c. Metode NPV (Net Present Value) } \\
& \text { Merupakan metode analisis keuangan } \\
& \text { yang memperhatikan adanya perubahan nilai } \\
& \text { uang karena faktor waktu; proyeksi arus kas }
\end{aligned}
$$


dapat dinilai sekarang (periode awal investasi) melalui pemotongan nilai dengan faktor pengurang yang dikaitkan dengan biaya modal (persentase bunga).

NPV $=$ Total PV Aliran Kas Bersih - Total PV Investasi

Kriteria penilaian NPV adalah:

- Jika NPV > 0, maka investasi diterima.

- Jika NPV <0, maka investasi ditolak.

d. Metode PI (Profitability Index)

Metode PI (Profitabilitas Indeks) Indeks profitabilitas adalah rasio atau perbandingan antara jumlah nilai sekarang arus kas selama umur ekonomisnya dan pengeluaran awal proyek.

$$
P I=\frac{\text { Nilai Aliran Kas Masuk }}{\text { Nilai Investasi }}
$$

Kriteria untuk profitabilitas indeks :

- Jika PI > 1 maka investasi tersebut dapat dijalankan.

- Jika PI < 1 maka investasi tersebut tidak layak dijalankan

e. Efisiensi Usaha (R/C Ratio)

Merupakan perbandingan antara TR

(Total Revenue) atau Total Penerimaan dengan TC (Total Cost) atau Total Biaya Produksi. Adapun kriteria pengujian R/C Ratio adalah sebagai berikut :

$$
\begin{aligned}
& \text { R/C Ratio }=\frac{T R}{T C} \\
& \text { Dengan : } \\
& \text { TR }=\mathrm{P} \times \mathrm{Q} \\
& \mathrm{TC} \quad=\mathrm{TFC}+\mathrm{TVC} \\
& \text { Keterangan : } \\
& \mathrm{TR} \quad=\text { Total Revenue } \\
& \mathrm{TC} \quad=\text { Total Cost } \\
& \mathrm{P} \quad=\text { Price } \\
& \mathrm{Q} \quad=\text { Quantity } \\
& \mathrm{TFC} \quad=\text { Total Fixed Cost } \\
& \mathrm{TVC} \quad=\text { Total Variabel Cost }
\end{aligned}
$$

Adapun kriteria penghitungan $\mathrm{R} / \mathrm{C}$ ratio adalah sebagai berikut :

$\mathrm{R} / \mathrm{C}<1=$ Usaha tidak efisien dan merugikan $\mathrm{R} / \mathrm{C}>1=$ Usaha Efisien dan menguntungkan $\mathrm{R} / \mathrm{C}=1=$ Usaha tidak menguntungkan dan tidak merugikan

\section{HASIL DAN PEMBAHASAN}

Upaya yang Dilakukan PD. Carole Jaya dalam Mempertahankan Eksistensi Usahanya

Dalam rangka mempertahankan eksistensi usahanya, PD. Carole Jaya memutuskan untuk mengembangkan produk baru berbahan dasar daging sapi segar yaitu berupa dendeng daging sapi.

\begin{tabular}{|c|c|c|c|c|}
\hline No. & Uraian & Quantitas & Harga (Rp) & Jumlah (Rp) \\
\hline 1. & Daging sapi segar & $50 \mathrm{Kg}$ & 120.000,- & $6.000 .000,-$ \\
\hline 2. & Bawang Putih & $1,25 \mathrm{Kg}$ & 40.000 :- & 50.000 \\
\hline 3. & Gula Pasir & $12,5 \mathrm{Kg}$ & 19.000,- & 237.500,- \\
\hline 4. & Ketumbar & $2,5 \mathrm{Kg}$ & 15.000,- & $37.500,-$ \\
\hline 5. & Serai & $1 / 4 \mathrm{Kg}$ & 12.000,- & $3.000,-$ \\
\hline 6. & Lengkuas & $3 \mathrm{Kg}$ & 10.000,- & $40.000,-$ \\
\hline 7. & Garam & $0,25 \mathrm{Kg}$ & 8.000 ;- & $2.000,-$ \\
\hline 8. & Standing Pouch & 1 Set & 160.000 :- & $160.000,-$ \\
\hline & \multicolumn{3}{|c|}{ TOTAL } & $6.530 .000,-$ \\
\hline
\end{tabular}

\section{Kelayakan Investasi Usaha dalam Usaha} Dendeng Daging Sapi pada PD. Carole Jaya

Untuk menghitung kelayakan investasi usaha dendeng daging sapi ini diperlukan data-data keuangan diantaranya adalah data biaya tetap, biaya variabel dan cashflow. Untuk menghitung data tersebut, dibutuhkan beberapa data sebagai berikut:

Tabel 1. Bahan-Bahan Dendeng Daging Sapi Per Produksi

Tabel 2. Biaya Tetap (Fix Cost) / Bulan

\begin{tabular}{|c|l|r|}
\hline N0. & \multicolumn{1}{|c|}{ Uraian } & Harga / Bulan (Rp) \\
\hline 1. & Biaya Transportasi & $150.000,-$ \\
2. & Listrik dan air & $100.000,-$ \\
3. & Telepon dan kuota data Intemet & $100.000,-$ \\
4. & Upah Tenaga Kerja & $800.000,-$ \\
\hline & Jumlah & $1.150 .000,-$ \\
\hline
\end{tabular}


Tabel 3 Biaya Variabel Pembuatan Dendeng Daging Sapi

\begin{tabular}{|c|c|c|c|c|c|c|c|c|c|c|}
\hline No. & Uraian & Qty & $\begin{array}{c}\text { Harga } \\
\text { Satuan } \\
(\mathrm{Rp})\end{array}$ & $\begin{array}{c}\text { Biaya per } \\
\text { satu kali } \\
\text { produksi } \\
(\mathrm{Rp})\end{array}$ & \begin{tabular}{|c|} 
Jumlah \\
Bulan ke-l \\
(Feb.2018) \\
2 kali \\
produksi \\
(Rp) \\
\end{tabular} & $\begin{array}{c}\text { Jumlah } \\
\text { Bulan ke-2 } \\
\text { (Mar.2018) } \\
2 \text { kali } \\
\text { produksi } \\
(\mathrm{Rp}) \\
\end{array}$ & \begin{tabular}{|c|} 
Jumlah \\
Bulan ke-3 \\
(Apr.2018) \\
3 kali \\
produksi \\
$(\mathrm{Rp})$ \\
\end{tabular} & \begin{tabular}{|c|} 
Jumlah \\
Bulan ke-4 \\
(Mei 2018) \\
3 kali \\
produksi \\
(Rp) \\
\end{tabular} & $\begin{array}{c}\text { Jumlah } \\
\text { Bulan ke-5 } \\
\text { (Juni 2018) } \\
4 \text { kali } \\
\text { produksi } \\
(\mathrm{Rp}) \\
\end{array}$ & $\begin{array}{c}\text { Jumlah } \\
\text { Bulan ke-6 } \\
\text { (Juli 2018) } \\
4 \text { kali } \\
\text { produksi } \\
\text { (Rp) } \\
\end{array}$ \\
\hline 1. & D & $50 \mathrm{~K}$ & 120.00 & 6.000 .00 & 12.000 .000 & 12.000 .000 & 18.000 .000 & 18.000 .000 & 24.000 .000 & 24.000 .000 \\
\hline 2. & & $1,25 \mathrm{~K}$ & $40.000,-$ & $50.000,-$ & 100.000 & 100.000 & 150.000 & 150.000 & 200.000 & 200.000 \\
\hline 3. & Gula Pasir & $12,5 \mathrm{Kg}$ & 19.000,- & 237.500:- & 475.000 & 475.000 & 712.500 & 712.500 & 950.000 & 950.000 \\
\hline 4. & & & 15.0 & 37. & 75. & 75.00 & 112.500 & 112.500 & 150.000 & 150.000 \\
\hline 5. & Se & $1 / 4 \mathrm{~K}$ & 12.0 & & 6. & 6.000 & 9.000 & 9.000 & 12.000 & 12.000 \\
\hline 6. & Lengkuas & $4 \mathrm{~K}$ & 10.0 & 40.0 & 80.000 & 80.000 & 120.000 & 120.000 & 160.000 & 160.000 \\
\hline 7. & Garam & $0,25 \mathrm{Kg}$ & 8.00 & 2.00 & 4.000 & 4.000 & 6.000 & 6.000 & 8.000 & 8.000 \\
\hline 8. & $\begin{array}{l}\text { Standing Pouch } \\
\text { Plastik }\end{array}$ & 1 set & 160.000 & $160.000,-$ & 320.000 & 320.000 & 480.000 & 480.000 & 640.000 & 640.000 \\
\hline & \multicolumn{4}{|c|}{ TOTAL } & 13.060 .000 & 13.060 .000 & 19.590 .000 & 19.590 .000 & 26.120 .000 & 26.120 .000 \\
\hline
\end{tabular}

Tabel 4 Pendapatan Bulan Februari 2018 s.d Juli 2018

\begin{tabular}{|c|c|c|c|c|c|c|c|}
\hline Bulas & $\begin{array}{c}\text { Proses } \\
\text { produksi }\end{array}$ & Produk & $\begin{array}{l}\text { Produksi } \\
\text { (bungkwe) }\end{array}$ & $\begin{array}{l}\text { Qty } \\
(\mathrm{Kg})\end{array}$ & $\begin{array}{c}\text { Harga } \\
\text { Joal } / \\
\text { Kemasan }\end{array}$ & $\begin{array}{c}\text { Pendapatas } \\
\text { (Rp) }\end{array}$ & $\begin{array}{l}\text { Total } \\
\text { Pendapaten } \\
\text { (Inflox) } \\
\text { (Rp) }\end{array}$ \\
\hline \multirow{3}{*}{$\begin{array}{c}\text { Feb } \\
2018\end{array}$} & \multirow{3}{*}{ 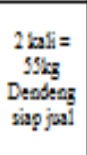 } & $\begin{array}{l}\text { Kemana } \\
100 \text { gam }\end{array}$ & $\begin{array}{l}250 \\
\text { bratess }\end{array}$ & $25 \mathrm{~kg}$ & 32000 & 8.000 .000 & \multirow{3}{*}{ 17.600.000, } \\
\hline & & $\begin{array}{l}\text { Remasan } \\
200 \text { gram }\end{array}$ & $\begin{array}{c}100 \\
\text { bratbss }\end{array}$ & $20 \mathrm{~kg}$ & 64.000 & 6.400 .000 & \\
\hline & & $\begin{array}{l}\text { Kemasa } \\
500 \text { gam }\end{array}$ & 20 bagtess & $10 \mathrm{~kg}$ & 160.000 & 3.200 .000 & \\
\hline \multirow{3}{*}{$\begin{array}{c}\text { Maret } \\
2018\end{array}$} & \multirow{3}{*}{$\begin{array}{c}2 \mathrm{kali}= \\
5 \mathrm{Fg} \\
\text { Deadeng } \\
\text { siap jai }\end{array}$} & \begin{tabular}{l|} 
Kemass \\
100 gram \\
\end{tabular} & $\begin{array}{c}270 \\
\text { brathos }\end{array}$ & $27 \mathrm{~kg}$ & 32000 & 8.540 .000 & \multirow{3}{*}{17.600 .000} \\
\hline & & $\begin{array}{l}\text { Kemasan } \\
2000 \text { gam }\end{array}$ & $\begin{array}{c}90 \\
\text { brathes }\end{array}$ & $18 \mathrm{~kg}$ & 64.000 & 5.760 .000 & \\
\hline & & $\begin{array}{l}\text { Kemass } \\
900 \mathrm{gram}\end{array}$ & 20 & $10 \mathrm{~kg}$ & 160.000 & 3.200 .000 , & \\
\hline \multirow{3}{*}{$\begin{array}{l}\text { April } \\
2018\end{array}$} & \multirow{3}{*}{ 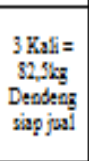 } & $\begin{array}{l}\text { Kemasas } \\
100 \text { gram } \\
\end{array}$ & $\begin{array}{c}295 \\
\text { bratsus }\end{array}$ & $29,5 \mathrm{~kg}$ & 32000 & 9.440.000, & \multirow{3}{*}{26.400 .000 , } \\
\hline & & $\begin{array}{l}\text { Kemasa } \\
200 \text { gram }\end{array}$ & $\begin{array}{c}225 \\
\text { bratess }\end{array}$ & $45 \mathrm{~kg}$ & 64.000 & 14.400 .000 & \\
\hline & & $\begin{array}{l}\text { Kemasa } \\
500 \text { gam }\end{array}$ & brathos & 8kg & 160.000 & 2.560 .000 & \\
\hline \multirow{3}{*}{$\begin{array}{l}\text { Mei } \\
2018\end{array}$} & \multirow{3}{*}{$\begin{array}{c}3 \mathrm{Kali}= \\
52, \mathrm{shz} \\
\text { Deadeag } \\
\text { siap jal }\end{array}$} & $\begin{array}{l}\text { Kemasa } \\
100 \text { gram }\end{array}$ & 360 & $32 \mathrm{~kg}$ & 32000 & $10.240 .000_{r}$ & \multirow{3}{*}{26.400 .000} \\
\hline & & $\begin{array}{l}\text { Kemana } \\
200 \text { gram }\end{array}$ & $\begin{array}{c}190 \\
\text { bratess }\end{array}$ & $35 \mathrm{~kg}$ & 64.000 & 12.160 .000 & \\
\hline & & $\begin{array}{l}\text { Kemasan } \\
500 \text { gram }\end{array}$ & $\begin{array}{c}23 \\
\text { bratess }\end{array}$ & $12,5 \mathrm{~kg}$ & 160.000 & 4.000.000, & \\
\hline \multirow{3}{*}{$\begin{array}{l}\text { Jumi } \\
2018\end{array}$} & \multirow{3}{*}{$\begin{array}{c}4 \mathrm{Kali}= \\
110 \mathrm{~kg} \\
\text { Deadeng } \\
\text { vapp jal }\end{array}$} & $\begin{array}{l}\text { Kemasan } \\
100 \text { gram } \\
\end{array}$ & $\begin{array}{l}400 \\
\text { baytess }\end{array}$ & $47 \mathrm{~kg}$ & 32000 & 15.040 .000 & \multirow{3}{*}{35.200 .000} \\
\hline & & $\begin{array}{l}\text { Kemasan } \\
200 \text { gram }\end{array}$ & $\begin{array}{c}190 \\
\text { bratess }\end{array}$ & $35 \mathrm{~kg}$ & 64.000 & 12.160 .000 & \\
\hline & & $\begin{array}{l}\text { Kemasas } \\
500 \text { gram }\end{array}$ & 50 & $25 \mathrm{~kg}$ & 160.000 & $8.000 .000_{-}$ & \\
\hline \multirow{3}{*}{$\begin{array}{c}\text { Juli } \\
2018\end{array}$} & \multirow{3}{*}{$\begin{array}{c}4 \mathrm{Kali}= \\
110 \mathrm{~kg} \\
\text { Deedeng } \\
\text { siap jal }\end{array}$} & $\begin{array}{l}\text { Kemana } \\
100 \text { gam }\end{array}$ & $\begin{array}{l}420 \\
\text { bratess }\end{array}$ & $42 \mathrm{~kg}$ & 32000 & 13.440 .000 & \multirow{3}{*}{$35.200 .000^{-}$} \\
\hline & & $\begin{array}{l}\text { Kemasa } \\
200 \text { gam }\end{array}$ & 250 & $50 \mathrm{~kg}$ & 64.000 & 16.000 .000 & \\
\hline & & $\begin{array}{l}\text { Kemassa } \\
500 \mathrm{zam}\end{array}$ & $\begin{array}{c}36 \\
\text { batess }\end{array}$ & 18kg & 160.000 & 5.760 .000 & \\
\hline
\end{tabular}

Biaya Produksi : $\frac{\text { Total Biaya (Fixed Cost }+ \text { Variable Cost) }}{\text { Jumlah Barang yang diproduksi }}$

$: \frac{\text { Rp. } 1.150 .000+\text { Rp. } 13.060 .000}{55 \mathrm{Kg}}$
$: \frac{\text { Rp. } 14.210 .000}{55 \mathrm{Kg}}$
Jadi, biaya produksi dendeng sapi adalah: Rp. 258.500,- / Kg

Maka, harga pokok penjualannya adalah : Rp. $258.500,-/ \mathrm{Kg}+( \pm 20 \%=$ Rp. 320.000,PD. Carole Jaya mempunyai pertimbangan sendiri ketika menetapkan margin laba / keuntungan sebesar $20 \%$ dari harga pokok produksi per $\mathrm{kg}$ dendeng daging sapi, diantaranya adalah:

1. Daya beli masyarakat Majalengka.

2. Adanya produk pesaing yang berasal dari Bandung yang masuk ke pasar Majalengka dengan harga yang lebih murah.

3. Sosialisasi dan promosi yang masih terbatas untuk wilayah kabupaten Majalengka saja

\section{Hasil Analisis Keuangan}

1. Payback Periode (PBP)

Payback Periode : $\left[\frac{\text { Jumlah Investasi }}{\text { Aliran Kas Bersih }}\right]$

$:\left[\frac{(\text { Biaya Variabel }+ \text { Biaya Tetap })}{(\text { Total Pendapatan }- \text { Total Biaya })}\right] X$ periode waktu investasi $[\underline{(13.0600 .000+13.060 .000+19.590 .000+19.590 .000+26.120 .000+26.120 .000+(1.150 .000 \text { X } 6 \text { Bulan })}]$ $=\left[\frac{117.540 .000}{(158.400 .000-117.540 .000)}\right]$ 
$=\left[\frac{117.540 .000}{40.860 .000}\right]$

$=2,876$ dibulatkan menjadi 3

Artinya adalah payback periode investasi dendeng daging sapi ini adalah 3 bulan sementara periode waktu investasi adalah 6 bulan, artinya, periode pengembalian investasi ini memenuhi syarat / layak untuk dijalankan.

2. ARR (Average Rate Of Return)

$$
\begin{gathered}
A R R=\frac{\text { Rata }- \text { rata EAT }(\text { Average Earning After Tax })}{\text { Rata }- \text { rata Investasi (Average Investment) }} \times 100 \% \\
\text { Rata }- \text { rata } E A T=\frac{\text { Total EAT }}{\text { Umur Ekonomis (n) }} \\
\text { Rata }- \text { rata Investasi }=\frac{\text { Investasi }}{\text { Umur Ekonomis (n) }} \\
\text { Rata }- \text { rata EAT }=\frac{158.400 .000}{6 \text { bulan }} \\
\text { Rata }- \text { rata Investasi }=\frac{117.540 .000}{6 \text { bulan }} \\
\text { ARR }=\frac{26.400 .000}{19.590 .000} \times 19.590 .000 \\
\text { ARR }=1,35 \%
\end{gathered}
$$

Bila ARR sebesar $1,35 \%>1$ artinya adalah Investasi ini layak diterima dan layak untuk dijalankan.

\section{NPV (Net Present Value)}

Untuk menghitung NPV, harus mengetahui suku bunga Bank yang berlaku saat ini, dan saat ini suku bunga Bank yang berlaku adalah sebesar $12 \%$ per tahun. Sementara dalam analisis ini, periode investasi yang digunakan adalah bulanan. Maka harus dikonversikan dulu ke suku bunga per bulan.

NPV = Total PV Aliran Kas Bersih - Total PV Investasi

$$
\begin{aligned}
\mathrm{NPV}= & \mathrm{Ab}(\mathrm{P} / \mathrm{A}, \mathrm{i}, \mathrm{n})-\mathrm{AI}(\mathrm{P} / \mathrm{A}, \mathrm{i}, \mathrm{n}) \\
= & 26.400 .000(\mathrm{P} / \mathrm{A}, 12,6)- \\
& 19.590 .000(\mathrm{P} / \mathrm{A}, 12,6) \\
= & 26.400 .000(4,1114)- \\
& 19.590 .000(4,1114) \\
= & 1.540 .960-80.542 .326 \\
= & 27.998 .634,-
\end{aligned}
$$

Karena kriteria NPV > 1, artinya investasi akan menguntungkan / layak (feasible).

4. PI (Profitability Index)

$$
\begin{aligned}
P I & =\frac{\text { Nilai Aliran Kas Masuk }}{\text { Nilai Investasi }} \\
P I & =\frac{158.400 .000}{117.540 .000} \\
P I & =1,35
\end{aligned}
$$

Profitability Index sebesar 1,35 artinya adalah investasi tersebut dapat dijalankan (feasible).

$$
\begin{aligned}
& \text { 5. Efisiensi Usaha (R/C Ratio) } \\
& \text { R/C Ratio }=\frac{T R}{T C} \\
& \text { Dengan TR }=\mathrm{P} \times \mathrm{Q} \\
& \mathrm{TC}=\mathrm{TFC}+\mathrm{TVC}
\end{aligned}
$$

Keterangan:

$\mathrm{TR}=$ Total Revenue

$\mathrm{TC}=$ Total Cost

$\mathrm{P} \quad=$ Price

$\mathrm{Q}=$ Quantity

TFC = Total Fixed Cost

TVC $=$ Total Variabel Cost

$$
\begin{aligned}
\mathrm{TR} & =320.000 \times 495 \mathrm{Kg} \\
& =158.400 .000,- \\
\mathrm{TC} & =(1.150 .000 \times 6)+(13.060 .000+ \\
& 13.060 .000+19.590 .000+ \\
& 19.590 .000+26.120 .000+ \\
& 26.120 .000) \\
& =\mathbf{1 1 7 . 5 4 0 . 0 0 0}
\end{aligned}
$$

Maka, R/C Ratio $=\frac{T R}{T C}$

$=\frac{158.400 .000}{117.540 .000}$

$=1,35$

R/C Ratio sebesar 1,35 artinya adalah, investasi ini menguntungkan. 
6. Break Event Point

a. BEP (Rp) Produksi

$=\frac{\text { Total Biaya }(\text { Fixed Cost }+ \text { Variable Cost })}{\text { Jumlah Barang yang diproduksi }}$

$=\frac{\text { Rp. } 1.150 .000+\text { Rp. } 13.060 .000}{55 \mathrm{Kg}}$

$=$ Rp. $258.500,-$

Artinya, dengan jumlah produksi sebanyak $55 \mathrm{Kg}$ dan total biaya $\mathrm{Rp} 14.210 .000$,- maka untuk mencapai titik impas, harga jual dendeng paling minimal adalah Rp. 258.500,- per Kg.

b. BEP Unit

$=\frac{\text { Total Biaya }(\text { Fixed Cost }+ \text { Variable Cost })}{\text { Harga Jual }}$

$=\frac{14.210 .000}{320.000}$

$=44,4$

Artinya, dengan biaya Rp 14.210.000,- dan harga jual Rp. 320.000,- maka untuk mencapai titik impas, jumlah dendeng paling minimal yang terjual adalah $44,4 \mathrm{Kg}$.

\section{KESIMPULAN DAN SARAN Kesimpulan}

Untuk mempertahankan eksistensi dalam dunia usaha, PD. Carole Jaya melakukan upaya pembuatan dendeng daging sapi.

a. Proses pembuatan dendeng daging sapi yang dilakukan oleh PD. Carole Jaya menggunakan bahan-bahan dan peralatan yang sederhana dan mudah dilakukan oleh siapapun.

b. Upaya pembuatan dendeng daging sapi ini sangat layak dan menguntungkan bagi PD. Carole Jaya.

\section{Saran}

Penelitian ini diharapkan dapat memberikan manfaat baik bagi mahasiswa, dosen dan perguruan tinggi dan masyarakat umum yang berminat pada dunia wirausaha. a. Bagi mahasiswa, penelitian ini diharapkan mampu memberikan informasi dan bahan pertimbangan untuk belajar menganalisis kelayakan sebuah usaha.

b. Bagi dosen, penelitian ini diharapkan mampu memberikan informasi dan menambah referensi untuk menganalisis kelayakan sebuah usaha.

c. Bagi perguruan tinggi, penelitian ini diharapkan mampu menjadi referensi dalam menganalisis sebuah usaha yang akan bermanfaat untuk mata kuliah kewirausahaan.

d. Bagi masyarakat umum, penelitian ini diharapkan mampu menjadi acuan dalam menganalisis kelayakan sebuah usaha, terutama bagi masyarakat yang bergelut di bidang wirausaha.

\section{DAFTAR PUSTAKA}

Giatman, M. (2017). Ekonomi Teknik. Jakarta: PT. Rajagrafindo Persada.

Kasmir \& Jakfar. (2007). Studi Kelayakan Bisnis, Edisi 2. Kencana, Jakarta.

Kodoatie, R. J. (2005). Analisis Ekonomi Teknik. Yogyakarta: Andi Offset.

Muzakhir, F. (2007). Analisis Penilaian Investasi Bisnis Waralaba Ritel Swalayan Pada CV. Baswara Investama. Universitas Gunadarma, Jakarta. Husein Umar. 2005. Studi Kelayakan Bisnis, Edisi 3. Jakarta: PT Gramedia Pustaka Utama.

Puryani, A. R. (2017). Ekonomi Teknik. Yogyakarta: Graha Ilmu.

Subagyo, A. (2008). Studi Kelayakan Teori dan Aplikasi. Jakarta: PT Elex Media Komputindo.

Widianto, M. (2008). Analisis Kelayakan Investasi Untuk Pengembangan Usaha

Pada CV. Usaha Hidup Istiqomah. Bekasi: Universitas Gunadarma. 
Waldiyono, M. S. (2008). Ekonomi Teknik (Konsep, Teori dan Aplikasi). Yogyakarta: Pustaka Pelajar.
Yusuf, L. (2008). Analisis Kelayakan Investasi Usaha PT. Istindo Mitra Perdana. Bekasi: Universitas Gunadarma. 